\title{
New Metabolites of Phenthoate in Mammalian Systems
}

\author{
Kazuki Toeda, Toru Miyamoto, Shigeru Kato* \\ and Izuru Yamamoto \\ Department of Agricultural Chemistry, Tokyo University of Agriculture, \\ Setagaya-ku, Tokyo 156, Japan \\ *NODAI Research Institute, Tokyo University of Agriculture, \\ Setagaya-ku, Tokyo 156, Japan
}

(Received November 21, 1983)

\begin{abstract}
Twelve transformation products from phenthoate (PAP) $\left[\left(\mathrm{CH}_{3} \mathrm{O}\right)_{2} \mathrm{P}(\mathrm{S}) \mathrm{SCH}(\mathrm{Ph}) \mathrm{COOC}_{2} \mathrm{H}_{5}\right]$ were identified by using intact mice, rat liver subcellular fractions and peracid. Other than those previously reported, five products were newly found: $\left(\mathrm{CH}_{3} \mathrm{O}\right)_{2} \mathrm{P}(\mathrm{O}) \mathrm{SCH}(\mathrm{Ph}) \mathrm{COOH}$ by mice and microsome-NADPH system (mfo), $\mathrm{CH}_{3} \mathrm{~S}(\mathrm{O}) \mathrm{CH}(\mathrm{Ph}) \mathrm{COOH}$ by mice, $\mathrm{HOCH}(\mathrm{Ph})-$ $\mathrm{COOC}_{2} \mathrm{H}_{5}$ by mice, mfo and cytosol, $\left(\mathrm{CH}_{3} \mathrm{~S}\right)\left(\mathrm{CH}_{3} \mathrm{O}\right) \mathrm{P}(\mathrm{O}) \mathrm{SCH}(\mathrm{Ph}) \mathrm{COOC}_{2} \mathrm{H}_{5}(\mathrm{PAP} S$-isomer $)$ by mfo and $\left(\mathrm{CH}_{3} \mathrm{O}\right)_{2} \mathrm{P}(\mathrm{O}) \mathrm{SSCH}(\mathrm{Ph}) \mathrm{COOC}_{2} \mathrm{H}_{5}$ (phosphinyl disulfide) by peracid oxidation. Based on the identification of the products, the initial modifications seem to occur in five ways on PAP: i) hydrolysis of carboxy ethyl ester; ii) demethylation; iii) formation of phosphorus oxythionate; iv) cleavage of $\mathrm{C}-\mathrm{S}$ bond; and $\mathrm{v}$ ) isomerization. Further modifications result in various products. Twenty-three unidentified metabolites were found. PAP $S$-isomer by mfo and phosphinyl disulfide by peracid oxidation are considered to be produced in mice, but their instability does not allow their finding.
\end{abstract}

The organophosphorus insecticide phenthoate (dimethyl $S$ - $\alpha$-ethoxycarbonylbenzyl phosphorodithioate or PAP) has low toxicity to mammals, while highly effective against various pest insects. Its fate in plants, houseflies, mice, air, soils and water, and decomposition by light have been reported. ${ }^{1-4)}$ Also, enantiomers of PAP were prepared and compared in terms of toxicity and efficacy. ${ }^{5)}$ This paper reports the metabolic fate of PAP in animals with emphasis on new metabolites by using peracid, rat liver subcellular fractions and intact mice.

\section{MATERIALS AND METHODS}

\section{1. ${ }^{14} C-P A P$}

${ }^{14} \mathrm{C}-\mathrm{PAP}$ was provided by Sumitomo Chemical Co., Ltd. Specific activity was $5.67 \mathrm{mCi}$ / mmol, over $99 \%$ purity.

\section{Reference Compounds}

Structures and designations are given in Table 1. All the compounds except 1, 22 and
23 were synthesized in our laboratory which will be reported elsewhere.

\section{Thin-layer Chromatography (TLC)}

Silica gel chromatoplate (Merck $60 \mathrm{~F}_{254}$, precoated, $0.2 \mathrm{~mm}$ with fluorescence indicator) was used for one or two dimensional separation. Eight solvent systems used and the $R f$ values of the reference compounds are listed in Table 1.

\section{Gas Chromatography-Mass Fragmentography} $(M F)$ and -Mass Chromatography $(M C)$

A Shimadzu Auto GCMS-6020 gas chromatograph-mass spectrometer was used for $\mathrm{MF}$ and MC. Operating conditions were as follows: column, a silanized $50 \mathrm{~cm} \times 2.5 \mathrm{~mm}$ i.d. glass column packed with $5 \%$ OV-1 on Gas chrom Q (60-80 mesh); flow rate of carrier gas, helium, $15 \mathrm{ml} / \mathrm{min}$; ionization source, $260^{\circ} \mathrm{C}$; ionizing voltage, $20 \mathrm{eV}$; accelerating voltage, $3.5 \mathrm{kV}$. The monitoring ions which were selected for $\mathrm{MF}$ and $\mathrm{MC}$ of compounds and 


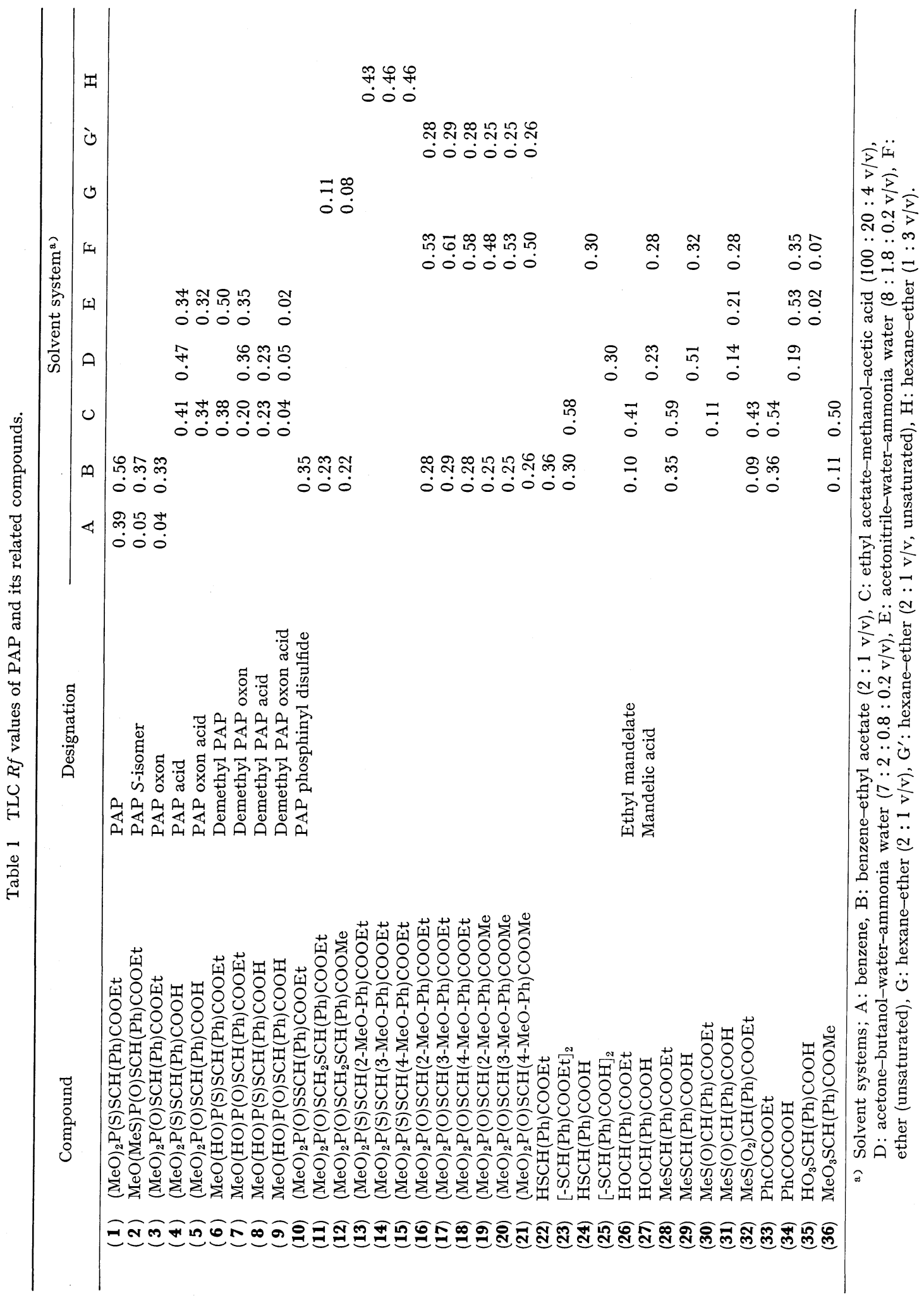


Table 2 Monitering ions and $R t$ of chemicals on MC and MF analysis.

\begin{tabular}{lccl}
\hline \multicolumn{1}{c}{ Chemicals } & $\begin{array}{c}\text { Analytical } \\
\text { mode }\end{array}$ & $m / z$ of monitering ion & $R t$ (column oven temperature, ${ }^{\circ} \mathrm{C}$ ) \\
\hline PAP (1) & MF & $274,273,217$ & $2.03(225)$ \\
PAP S-isomer (2) & MF & $274,273,245,217$ & $2.76(225)$ \\
PAP oxon (3) & MF & 258 & $1.62(225)$ \\
Ethyl mandelate (26) & MF & 180,107 & $2.58(140)$ \\
Compound 32 & MF & 164,163 & $1.86(210)$ \\
Compounds 13, 14 and 15 & MF & 304,193 & $13,2.92 ; 14,3.19 ; 15,3.71(230)$ \\
Compounds 16, 17 and 18 & MC & 288,193 & $16,2.35 ; 17,2.56 ; 18,2.52(230)$ \\
Compound 11 & MF & 208,187 & $1.88(230)$ \\
Methyl ester of compound 4 & MC & $306,274,246,125$ & $\left.7.90^{\mathrm{a}}\right)$ \\
Methyl ester of compound $\mathbf{5}$ & MF & $290,258,231$ & $1.91(215)$ \\
Compounds 19, 20 and 21 & MC & $288,177,151$ & $19,2.01 ; 20,2.20 ; 21,2.71(230)$ \\
Compound 12 & MF & 194,187 & $1.65(230)$
\end{tabular}

a) Temperature programming: $150^{\circ} \mathrm{C}$ for $1 \mathrm{~min}$, then $150-280^{\circ} \mathrm{C}\left(8^{\circ} \mathrm{C} / \mathrm{min}\right)$.

column temperatures were shown in Table 2.

\section{Radioactivity Assay}

Radioactive compounds were detected on the plates by autoradiography with a SAKURA $\mathrm{X}$-ray film. A radioactive silica gel zone was cut from the plate, kept overnight in a vial with the following scintillator mixture and the radioactivity was counted with an Aloka LSC-903 liquid scintillation counter. The above samples or any organosoluble samples were added with $10 \mathrm{ml}$ of scintillator mixture (DPO $4 \mathrm{~g}$, POPOP $0.1 \mathrm{~g}$, toluene $600 \mathrm{ml}$ and ethyl cellosolve $400 \mathrm{ml}$ ). Aquatic samples were mixed with $10 \mathrm{ml}$ of Aquazol-2 (New England Nuclear). Solid samples were burned in an Aloka ASC-112 automatic sample combustion system.

\section{EXPERIMENTAI}

\section{Peracid Oxidation}

To ${ }^{14} \mathrm{C}$-PAP (15 mg, $1.4 \times 10^{6} \mathrm{dpm}$ ) in $5 \mathrm{ml}$ of $\mathrm{CH}_{2} \mathrm{Cl}_{2}$, a solution of 3-chloroperbenzoic acid (MCPBA, purity $80 \%, 10.2,20.4$ or $30.6 \mathrm{mg}$ which correspond to equi-, twice or thrice moles to PAP) in $5 \mathrm{ml}$ of $\mathrm{CH}_{2} \mathrm{Cl}_{2}$ was added dropwise under ice-cooled conditions. After the addition the mixture was stirred for $15 \mathrm{~min}$ and kept overnight at $-20^{\circ} \mathrm{C}$. A portion of the reaction mixture was submitted to two dimensional TLC (systems C and B). A complicated chromatogram (not shown) suggested decomposition of products on TLC. This

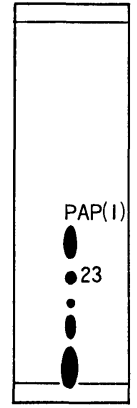

Solvent A

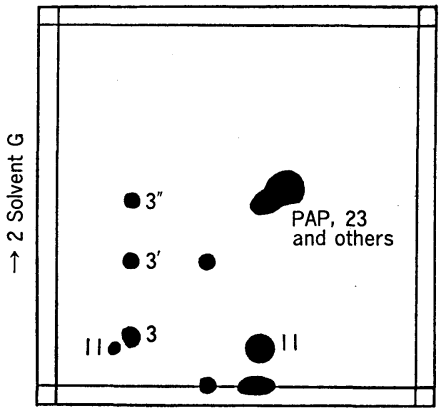

$\rightarrow$ I Solvent $G$
Fig. 1 TLC autoradiograms showing peracid oxidation products of ${ }^{14} \mathrm{C}$-PAP.

UV irradiation was made after the first development (see text).

might be caused by production of unstable PAP phosphinyl disulfide (10) which is expected as a product of peracid oxidation of phosphorodithioate. ${ }^{6)}$ Therefore, other approach was tried (Fig. 1). Firstly, the reaction mixture was developed with system A. PAP $(R f$ $0.39)$ and $[-\mathrm{SCH}(\mathrm{Ph}) \mathrm{COOEt}]_{2}$ (23) (Rf 0.30) were identified. The spots of lower $R f$ values seem to include many products. Secondly, the reaction mixture was added with an excess amount of diazomethane in ether and kept for $3 \mathrm{hr}$ in dark at $4^{\circ} \mathrm{C}$. This procedure aims to stabilize phosphinyl disulfide by derivatization and is expected to give the following reaction (a) if PAP phosphinyl 


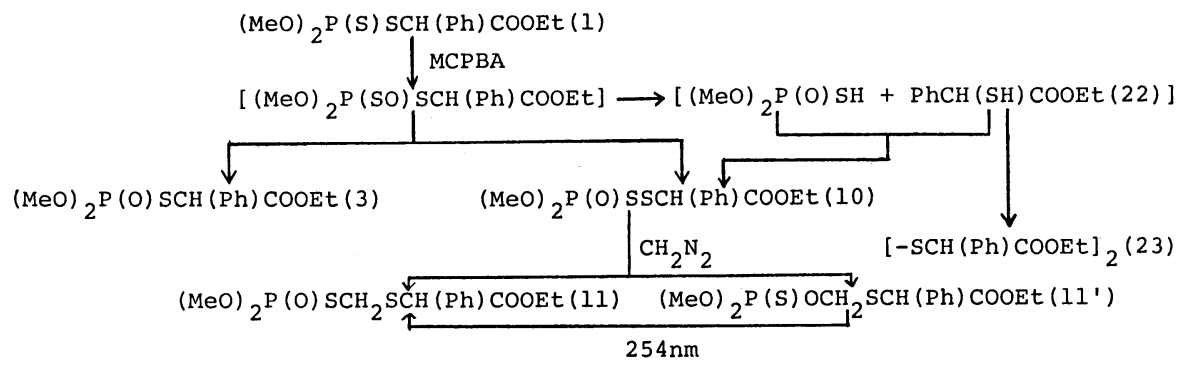

Fig. 2 Peracid oxidation of ${ }^{14} \mathrm{C}-\mathrm{PAP}$ and reaction of product with $\mathrm{CH}_{2} \mathrm{~N}_{2}$.

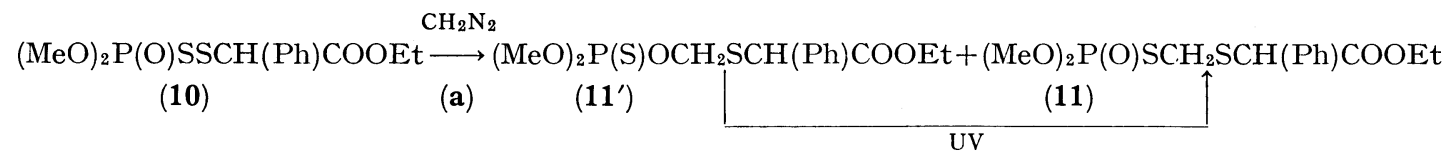

disulfide $(\mathbf{1 0})$ is really produced by peracid oxidation.

The reaction mixture was submitted to two dimensional TLC. First it was developed with system G, thereafter irradiated with ultraviolet light $(254 \mathrm{~nm})$ for $3 \mathrm{hr}$ (this treatment converts compound $\mathbf{1 1}^{\prime}$ to $\mathbf{1 1}$ ), then developed in second direction with the same solvent system. PAP, compound $\mathbf{2 3}$ and some others overlapped. Compound 11' was not separable from PAP in the first development, but after irradiation it changed to compound $\mathbf{1 1}$ and was separable as shown. Therefore, combined amount of the compounds $\mathbf{1 1}$ and $\mathbf{1 1}$ ' represents the amount of PAP phosphinyl disulfide (10). PAP oxon (3) was separable from other products, but by irradiation it gave two more spots $\left(\mathbf{3}^{\prime}\right.$ and $\left.\mathbf{3}^{\prime \prime}\right)$. The combined amount of $\mathbf{3}$,

Table 3 Peracid oxidation products of ${ }^{14} \mathrm{C}-\mathrm{PAP}$.

\begin{tabular}{lrrr}
\hline \multirow{2}{*}{ Product } & \multicolumn{4}{c}{ Products found (\%) } \\
\cline { 2 - 4 } & \multicolumn{3}{c}{ MCPBA/PAP ratio } \\
& 1 & 2 & 3 \\
\hline PAP (1) & 46.0 & 12.1 & 8.0 \\
PAP oxon (3) & 31.6 & 29.6 & 34.1 \\
PAP phosphinyl & 8.6 & 18.5 & 12.8 \\
$\quad$ disulfide (10) & 1.7 & 4.2 & $<7.3$ \\
[-SCH(Ph)COOEt $]_{2}$ & $123)$ & 35.6 & $>37.8$ \\
Others & 12.1 & 100 & 100 \\
\hline Total & 100 & 100 \\
\hline
\end{tabular}

$\mathbf{3}^{\prime}$ and $\mathbf{3}^{\prime \prime}$ corresponds to the amount of PAP oxon formed by peracid oxidation. Table 3 indicates the net result of the peracid oxidation of PAP. Although the ratio of the products depended on peracid/PAP ratio, this finding indicates the occurrence of the reaction shown in Fig. 2.

2. In vitro Metabolism of ${ }^{14} C-P A P$ with Rat Liver Subcellular Fraction

\subsection{Enzyme system}

Microsome and cytosol fractions were prepared by the conventional method. Incubation mixture consists of ${ }^{14} \mathrm{C}-\mathrm{PAP}(0.1 \mu \mathrm{mol}$, $1.33 \times 10^{6} \mathrm{dpm}$ ) in $0.1 \mathrm{ml}$ of $47 \%$ aqueous ethanol, $0.5 \mathrm{ml}$ of microsome or cytosol solution corresponding to $20 \%$ homogenate in $0.25 \mathrm{~m}$ sucrose, NADPH or GSH $(5 \mu \mathrm{mol})$ in $0.1 \mathrm{ml}$ of $0.25 \mathrm{M}$ sucrose and $1.3 \mathrm{ml}$ of $0.25 \mathrm{M}$ sucrose in $1 / 15 \mathrm{~m}$ phosphate buffer (total $2 \mathrm{ml}$ ). Three $\mathrm{pH}$ levels, 6.5, 7.0 and 7.5, were set up.

\subsubsection{Microsome}

After incubation with microsome at $37^{\circ} \mathrm{C}$ for $15 \mathrm{~min}$, the mixture was extracted twice each time with $15 \mathrm{ml}$ of $\mathrm{CH}_{2} \mathrm{Cl}_{2}$, then after adjusting to $\mathrm{pH} 1$ with $1 \mathrm{~N} \mathrm{HCl}$, it was extracted twice each time with $15 \mathrm{ml}$ of $\mathrm{CH}_{2} \mathrm{Cl}_{2}$. More than $90 \%$ of the applied radiocarbon was extracted into the combined extract. Therefore, identification of the PAP metabolites was conducted for this extract. The extract was separated by one dimensional TLC with systems $\mathrm{C}, \mathrm{B}$ and $\mathrm{A}$ as shown in Fig. 3. PAP(1), PAP oxon (3), PAP 
Table 4 Metabolism of ${ }^{14} \mathrm{C}-\mathrm{PAP}$ by rat liver microsome with or without NADPH under different $\mathrm{pH}$ conditions.

\begin{tabular}{|c|c|c|c|c|c|c|}
\hline \multirow{4}{*}{ Product } & \multicolumn{6}{|c|}{$\%$ of applied radiocarbon } \\
\hline & \multicolumn{6}{|c|}{$\mathrm{pH}$} \\
\hline & \multicolumn{2}{|c|}{7.5} & \multicolumn{2}{|c|}{7.0} & \multicolumn{2}{|c|}{6.5} \\
\hline & $\left.+{ }^{a}\right)$ & - & + & - & + & - \\
\hline $\operatorname{PAP}(\mathbf{1})$ & 1.5 & 0.8 & 2.6 & 0.5 & 6.1 & 1.3 \\
\hline$[-\mathrm{SCH}(\mathrm{Ph}) \mathrm{COOEt}]_{2}(\mathbf{2 3})$ & 0.3 & ND & 0.5 & $\mathrm{ND}$ & 0.7 & ND \\
\hline PAP oxon $(3)$ & 0.3 & ND & 2.0 & $\mathrm{ND}$ & 12.0 & 0.1 \\
\hline PAP acid (4) & 67.6 & 93.0 & 63.2 & 94.4 & 67.4 & 93.0 \\
\hline M-1 (Ethyl mandelate) & 1.4 & 0.3 & 2.1 & 0.3 & 2.2 & 0.9 \\
\hline M-2 (PAP $S$-isomer) & 0.9 & $\mathrm{ND}$ & 0.5 & ND & 0.4 & ND \\
\hline $\mathrm{M}-3$ & 0.3 & 0.1 & 0.6 & $\mathrm{ND}$ & 0.4 & 0.6 \\
\hline$M-4$ & 1.9 & 2.8 & 2.9 & 2.0 & 1.3 & 2.5 \\
\hline M-5 & 3.4 & ND & 3.0 & $\mathrm{ND}$ & 1.0 & ND \\
\hline M-6 & 0.5 & 1.3 & 0.5 & 0.4 & 0.3 & 0.3 \\
\hline M-7 (PAP oxon acid) & 12.2 & 0.1 & 12.3 & 0.1 & 2.8 & 0.1 \\
\hline Origin & 1.5 & 0.1 & 0.8 & 0.1 & 0.6 & 0.1 \\
\hline Aqueous fraction & 8.2 & 1.5 & 9.0 & 2.2 & 4.8 & 1.1 \\
\hline Total & 100 & 100 & 100 & 100 & 100 & 100 \\
\hline
\end{tabular}

a) + : with NADPH, - : without NADPH.

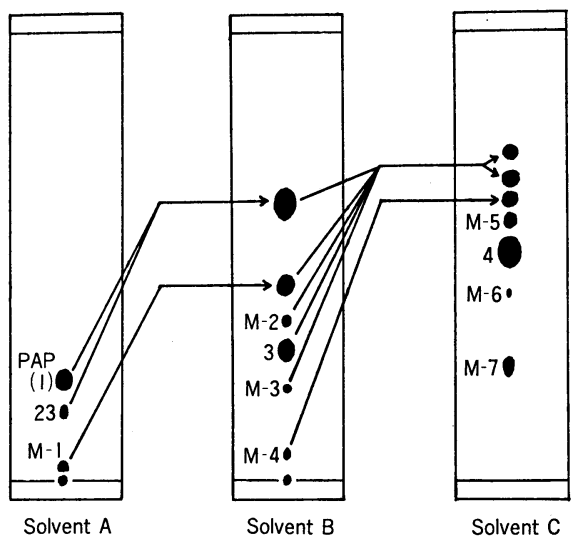

Fig. 3 TLC autoradiograms of metabolites of ${ }^{14} \mathrm{C}$-PAP by rat liver microsome.

acid (4), [-SCH(Ph)COOEt $]_{2}$ (23), M-1 through M-7 appeared on the chromatograms. Quantitation of these metabolites is shown in Table 4. With or without NADPH, PAP acid (4) was the major metabolite. Without NADPH, PAP acid (4) produced more than $93 \%$ at any $\mathrm{pH}$ examined. However, in the presence of $\mathrm{NADPH}$, it reduced to $63-67 \%$, and many minor metabolites appeared or increased in amount except M-4 and M-6. Also, oxon forma- tion at $\mathrm{pH} 6.5$ and $\mathrm{M}-7$ formation at $\mathrm{pH} 7.5$ and 7.0 became remarkable. Radiocarbon in the aqueous layer also increased with NADPH. M-1 was identified as ethyl mandelate (26) by $\mathrm{MC}$ as discussed later. Hydroxylation on the phenyl ring did not seem to occur because methylation of the extract did not give any corresponding spots to compounds $\mathbf{1 3}$ through 21. M-2 produced in the presence of NADPH seems to be PAP $S$-isomer (2) by $R f$ value. Confirmation was made by $\mathrm{MF}$ as discussed later. M-7 was identified as PAP oxon acid (5) by MC as discussed later.

\subsubsection{Cytosol}

After incubation with cytosol at $37^{\circ} \mathrm{C}$ for $60 \mathrm{~min}$, the mixture was adjusted to $\mathrm{pH} 1$ with $1 \mathrm{~N} \mathrm{HCl}$ and extracted thrice each time with $20 \mathrm{ml}$ of $\mathrm{CH}_{2} \mathrm{Cl}_{2}$. With cytosol fraction in the presence or absence of GSH, metabolism proceeded extensively. Identification of the metabolites in the extract was conducted by TLC as shown in Fig. 4. PAP (1), PAP acid (4), demethyl PAP (6), ethyl mandelate (26), S-1 through S-6 appeared on the chromatograms. Quantitation of these metabolites is shown in Table 5. With or without GSH, PAP acid (4) was the major metabolite. However, it decreased with GSH, while aqueous fraction, 
Table 5 Metabolism of ${ }^{14} \mathrm{C}-\mathrm{PAP}$ by rat liver cytosol with or without GSH under different $\mathrm{pH}$ conditions.

\begin{tabular}{|c|c|c|c|c|c|c|}
\hline \multirow{4}{*}{ Product } & \multicolumn{6}{|c|}{$\%$ of applied radiocarbon } \\
\hline & \multirow{2}{*}{\multicolumn{2}{|c|}{7.5}} & \multirow{2}{*}{\multicolumn{2}{|c|}{$\begin{array}{l}\mathrm{pH} \\
7.0\end{array}$}} & \multirow{2}{*}{\multicolumn{2}{|c|}{6.5}} \\
\hline & & & & & & \\
\hline & $+{ }^{\text {a })}$ & - & + & - & + & - \\
\hline $\operatorname{PAP}(\mathbf{1})$ & 4.5 & 1.7 & 2.0 & 7.1 & 7.8 & 9.7 \\
\hline Ethyl mandelate (26) & 0.8 & 0.9 & 0.8 & 0.6 & 1.3 & 1.0 \\
\hline PAP acid (4) & 60.3 & 74.1 & 55.6 & 80.4 & 48.6 & 79.4 \\
\hline Demethyl PAP (6) & 4.3 & 2.3 & 2.8 & 1.5 & 7.5 & 1.1 \\
\hline S-1 & 0.7 & 0.4 & 0.5 & 0.3 & 0.8 & 0.3 \\
\hline S-2 & 0.8 & 0.5 & 0.7 & 0.3 & 0.5 & 0.3 \\
\hline S-3 & 5.4 & 0.8 & 4.8 & 0.9 & 2.2 & 0.7 \\
\hline S-4 & 0.4 & 0.6 & 0.5 & 0.6 & 0.4 & 0.4 \\
\hline S-5 & 0.2 & 0.2 & 0.2 & $\mathrm{ND}$ & 0.4 & ND \\
\hline S-6 & 0.1 & 0.2 & 0.2 & ND & 0.1 & ND \\
\hline Origin & 0.1 & 0.2 & 0.1 & 0.2 & 0.1 & 0.2 \\
\hline Aqueous fraction & 22.4 & 18.1 & 31.8 & 8.1 & 30.3 & 6.9 \\
\hline Total & 100 & 100 & 100 & 100 & 100 & 100 \\
\hline
\end{tabular}

a) +: with GSH, - : without GSH.

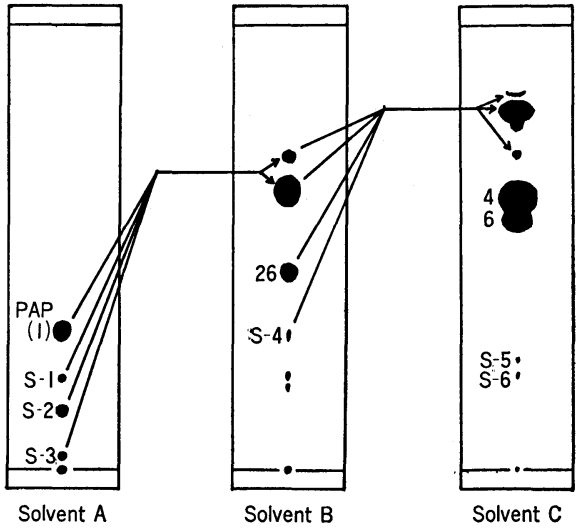

Fig. 4 TLC autoradiograms of metabolites of ${ }^{14} \mathrm{C}-\mathrm{PAP}$ by rat liver cytosol.

demethyl PAP (6) and several minor metabolites, particularly S-3, increased or appeared. This trend was more remarkable, in general, at lower pHs. This result suggests that with GSH, particularly at lower pHs, demethylation and conjugation by GSH $S$-transferaseGSH system proceed as well as hydrolysis of ethoxycarbonyl moiety by esterase system. Formation of ethyl mandelate (26) was not affected by GSH. For confirmation, ethyl mandelate (26), after the addition of unlabeled compound, was hydrolyzed to mandelic acid (27) with aqueous $1 \% \mathrm{NaOH}$ at $40^{\circ} \mathrm{C}$; $\mathrm{PAP}$ acid (4) and demethyl PAP (6) were treated with diazomethane to give the corresponding methylated derivatives.

\subsection{Phosphinyl disulfide}

Phosphinyl disulfide type compounds are generally unstable and requires derivatization with diazomethane for detection. As the formation of PAP phosphinyl disulfide (10) was confirmed by peracid oxidation, an attempt was made to find this compound from $\mathrm{CH}_{2} \mathrm{Cl}_{2}$ extract obtained on microsomeNADPH metabolism by the method which was successful for detecting the phosphinyl disulfide from $S$-(4-chlorophenyl) diethyl phosphorodithioate. ${ }^{7)}$ However, the corresponding compounds $\mathbf{1 1}$ and $\mathbf{1 1}^{\prime}$ were not detected. Probably PAP phosphinyl disulfide (10) is too unstable to be present in such incubation mixture.

\section{Analysis of PAP Metabolites from Un- labeled $P A P$ by $M F$ and $M C$}

Many metabolites were identified from ${ }^{14} \mathrm{C}$ PAP by cochromatography with the authentic compounds. However, more rigid confirmation will be required for some of the metabolites. For example, M-2 was assigned as PAP $S$ - 


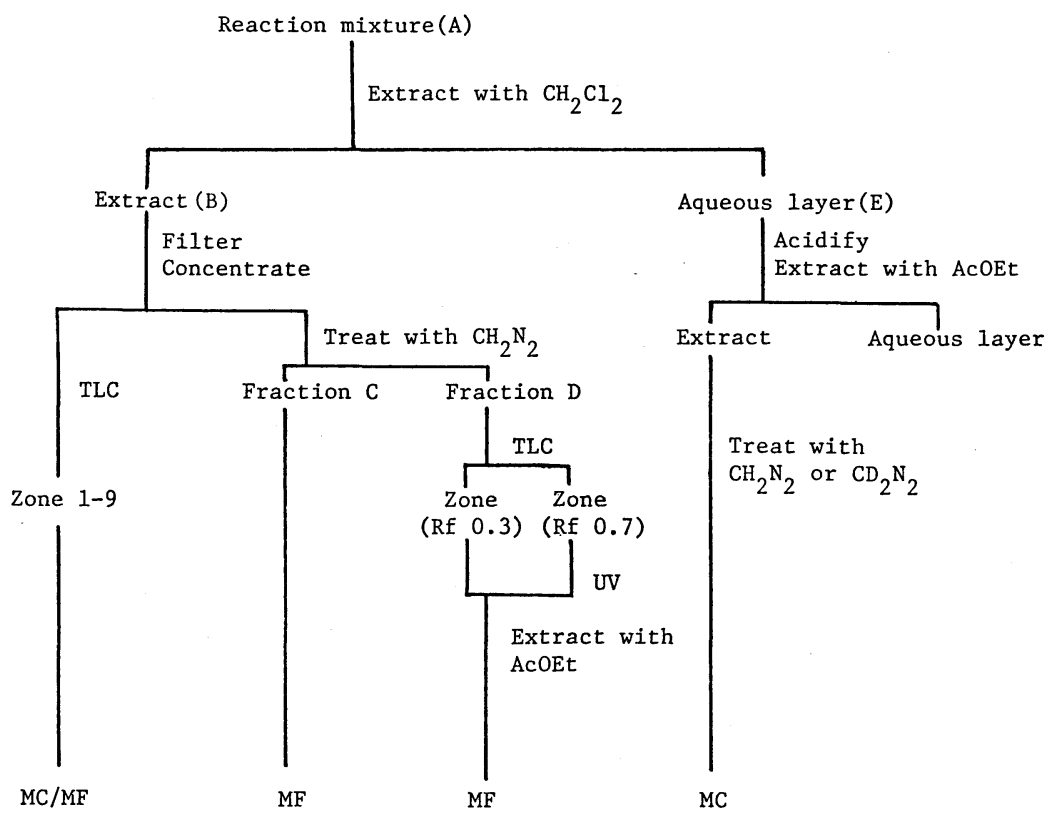

Fig. 5 Analysis by MF and MC of metabolites of PAP.

isomer, but such isomerization occurs usually by heat or light, and formation under biological conditions has only been reported recently by us for other compounds. ${ }^{7)}$ M-7 was methylated with diazomethane, and the methylated product and its photoproducts gave a little lower $R f$ values than PAP oxon (3) and its photoproducts on TLC (system B). Therefore, M-7 seems to be either PAP oxon acid (5) or PAP oxon hydroxylated on the phenyl moiety. In other aspects, other compounds having carboxylic acid or carboethoxy group are expected to be present as PAP metabolites. Identification of these metabolites was tried by MF and $\mathrm{MC}$ by the following procedures.

A microsomal incubation mixture consisted of PAP $(2 \mu \mathrm{M})$ in $2 \mathrm{ml}$ of $40 \%$ aqueous ethanol, $10 \mathrm{ml}$ of $20 \%$ homogenate of microsome in $0.25 \mathrm{~m}$ sucrose, NADPH $(100 \mu \mathrm{M})$ in $1.0 \mathrm{ml}$ of $0.25 \mathrm{~m}$ sucrose, and $26 \mathrm{ml}$ of $0.25 \mathrm{M}$ sucrose in $1 / 15 \mathrm{~m}$ phosphate buffer $(\mathrm{pH} 7.5$ ) (total 40 $\mathrm{ml}$ ). Modification was made by subtracting $\mathrm{NADPH}$ or $\mathrm{NADPH}$ plus microsome. After incubation at $37^{\circ} \mathrm{C}$ for $15 \mathrm{~min}$, the reaction was stopped by the addition of $5 \mathrm{ml}$ of $\mathrm{CH}_{2} \mathrm{Cl}_{2}$. Two sets of incubation were carried out and combined for the following treatment (see Fig. 5). The combined incubation mixture (A)
Table 6 Metabolites of PAP by rat liver microsome with or without NADPH.

\begin{tabular}{cccc}
\hline \multirow{2}{*}{ Product } & \multicolumn{3}{c}{ \% of products } \\
\cline { 2 - 4 } & + & - & $\mathrm{c}$ \\
\hline PAP oxon (3) & 0.13 & $\mathrm{ND}$ & $\mathrm{ND}$ \\
PAP $S$-isomer (2) & 3.90 & 1.90 & $\mathrm{ND}$ \\
\hline a) + : with NADPH, & - : without NADPH, \\
c: without NADPH and microsome.
\end{tabular}

was extracted thrice each time with $160 \mathrm{ml}$ of $\mathrm{CH}_{2} \mathrm{Cl}_{2}$. The extract (B) was dried over sodium sulfate, filtered through milipore filter $(0.5 \mu \mathrm{m})$ and concentrated under reduced pressure and below $30^{\circ} \mathrm{C}$. A portion was subjected to TLC with system $\mathrm{B}$ and separated into nine zones according to $R f$ values. By $\mathrm{MF}$ and/or $\mathrm{MC}$, PAP from zone 7, PAP $S$-isomer (2) and ethyl mandelate (26) from zone 5, and PAP oxon (3) from zone $\mathbf{4}$ were identified. Particular attention was paid for identification of PAP $S$ isomer. As Table 6 indicates, PAP $S$-isomer (2) as well as PAP oxon (3) did not produce when both NADPH and microsome were absent. The result indicates that isomerization of PAP to its thiolo isomer (2) occurred with 
mixed function oxidase system. Formation of ethyl mandelate (26) was also followed by MF. After incubation with microsomal system for 15 min at $\mathrm{pH} 6.5$ with or without NADPH, 0.15 or $0.04 \%$ was found, respectively. Therefore, formation of ethyl mandelate seems to be dependent on mixed function oxidase system. M-1 metabolite in Fig. 3, produced by microsomal system, corresponded to ethyl mandelate (26) in $R f$ values and $\mathrm{MeS}\left(\mathrm{O}_{2}\right) \mathrm{CH}(\mathrm{Ph}) \mathrm{COOEt}$ (32). However, the latter was not detected by $\mathrm{MC}$, therefore M-1 is ethyl mandelate.

Another portion of $\mathrm{CH}_{2} \mathrm{Cl}_{2}$ extract (B) was treated with diazomethane and divided into two fractions (C and D). Fraction $\mathrm{C}$ was searched by MF for detection of PAP or PAP oxon hydroxylated on the phenyl moiety (as the methylated products), but such products were not detected. Fraction D was used for search of PAP phosphinyl disulfide (10). TLC separation with system B into zones of $R f c a$. 0.3 and $c a$. 0.7 , followed by irradiation of zone of $R f 0.7$ with ultraviolet light and extraction of both zones with ethyl acetate, is expected to give a derivative of PAP phosphinyl disulfide (10) as described in sections 1 and 2.2. However, there was no indication of the presence by MF.

The aqueous layer (E) which contains acidic metabolites was acidified to $\mathrm{pH} 1$ with $1 \mathrm{~N} \mathrm{HCl}$ and extracted thrice each time with $160 \mathrm{ml}$ of ethyl acetate. The extract was dried over sodium sulfate, treated with diazomethane and concentrated for MC analysis. Methyl analogs of PAP and PAP oxon, $(\mathrm{MeO})_{2} \mathrm{P}(\mathrm{S}) \mathrm{SCH}(\mathrm{Ph})$ $\mathrm{COOMe}$ and $(\mathrm{MeO}){ }_{2} \mathrm{P}(\mathrm{O}) \mathrm{SCH}(\mathrm{Ph}) \mathrm{COOMe}$, were identified. The latter was identified as the methylated product of M-7. There is a possibility that M-7 is PAP oxon acid (5) or demethyl PAP oxon acid (9). To examine the possibility, M-7 was treated with deuterodiazomethane and submitted to $\mathrm{MC}$ to monitor the incorporation of deuterium into $\left[(\mathrm{MeO})_{2} \mathrm{P}(\mathrm{O}) \mathrm{SCH}\right]^{+}$and $\mathrm{M}^{+}$. The deuterium was incorporated into $\mathrm{M}^{+}$, but not into $\left[(\mathrm{MeO})_{2} \mathrm{P}(\mathrm{O}) \mathrm{SCH}\right]^{+}$. Therefore, $\mathrm{M}-7$ was confirmed as PAP oxon acid (5). By MC compound 12, $(\mathrm{MeO})_{2} \mathrm{P}(\mathrm{O}) \mathrm{SCH}_{2} \mathrm{SCH}(\mathrm{Ph}) \mathrm{COO}$ $\mathrm{Me}$, was not detected, thus further confirming the absence of PAP phosphinyl disulfide formation.

\section{In Vivo Metabolism of ${ }^{14} C-P A P$ in Mice}

Three doses of ${ }^{14} \mathrm{C}$-PAP, 25.0, 43.8 and 70.0 $\mathrm{mg} / \mathrm{kg}$ (each $10 \mu \mathrm{Ci}$ ), were given to mouse which correspond to $1 / 14,1 / 8$ and $1 / 5$ of $\mathrm{LD}_{50}$ values, respectively. ${ }^{14} \mathrm{C}-\mathrm{PAP}$ was prepared as emulsifiable concentrate (PAP-solpol-xylene, $11: 3: 6 \mathrm{w} / \mathrm{w}$ ) and then diluted with water to $80 \mu \mathrm{l} /$ mouse before administering orally to 5 male mice of ddN strain (5 weeks old, body weight 20-22 g), which were starved overnight before the administration of PAP.

Each mouse was confined in a metabolic cage. Urine, feces and expired gas were trapped at definite intervals. The urine was diluted with water, filtered through glass fiber and measured. Feces were homogenized with acetonitrile, filtered and the acetonitrile layer was measured. Expired gas was trapped in methyl cellosolve-ethanolamine $(2: 1 \mathrm{w} / \mathrm{w})$ mixture and the radioactivity was measured.

For study of radiocarbon level in blood, 4.5 $\times 10^{6} \mathrm{dpm} /$ mouse $(43.8 \mathrm{mg} / \mathrm{kg})$ of ${ }^{14} \mathrm{C}-\mathrm{PAP}$ was administered and at every definite interval five mice were anesthesized and the as much as possible was taken by syringe from the heart (1-2 $\mathrm{ml} /$ mouse). The blood was then diluted with heparin solution to $3 \mathrm{ml}$ and the radioactivity was measured.

The radioactivity in blood increased rapidly, reaching a maximum within $30 \mathrm{~min}$, then gradually decreased and was only detectable after $24 \mathrm{hr}$ (Fig. 6). Excretion of radiocarbon was mainly into urine. A small portion was found in feces, but not in expired gas. Effect of dose was not significant as shown in Fig. 7. Within $6 \mathrm{hr}$ about the half was excreted into urine, and within $24 \mathrm{hr}$ about $95 \%$ was excreted into urine. Feces represented only $1 \%$ or less.

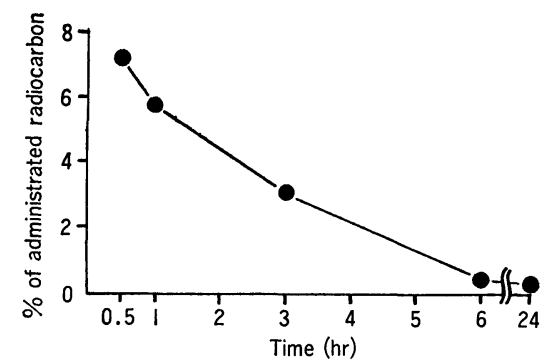

Fig. 6 Radioactivity level in blood after administration of ${ }^{14} \mathrm{C}-\mathrm{PAP}$ to male mice. 


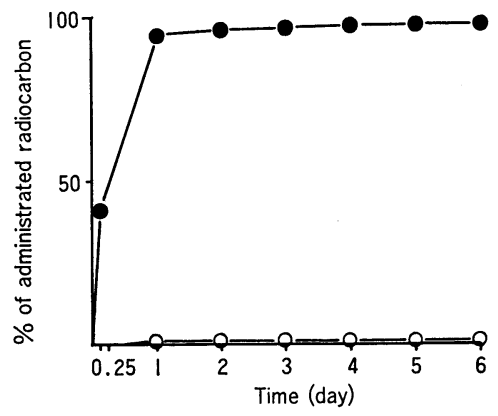

Fig. 7 Cumulative excretion of radiocarbon after oral administration of ${ }^{14} \mathrm{C}-\mathrm{PAP}$ to male mice (Dose $25-70 \mathrm{mg} / \mathrm{kg}$ ).

๑: urine, $\bigcirc$ : feces.

Complete excretion of radiocarbon was made after 8 days. The results indicate that the absorption of PAP is rapid, metabolism is extensive (as indicated later by nature of radiocarbon) and excretion is rapid and complete.

For identification of ${ }^{14} \mathrm{C}$-PAP metabolites urine from one day after the administration of $43.8 \mathrm{mg} / \mathrm{kg}$ was filtered through glass fiber, diluted to $25 \mathrm{ml}$ with water (count), acidified to $\mathrm{pH} 1$ with $1 \mathrm{~N} \mathrm{HCl}$, and extracted thrice each time with $100 \mathrm{ml}$ of ethyl acetate (count). The aqueous layer (count) was neutralized with $1 \mathrm{~N} \mathrm{NaOH}$ and its portion $(10 \mathrm{ml}, 1 \mu \mathrm{Ci})$ was concentrated under reduced pressure to a half, added with $0.5 \mathrm{ml}$ of $0.2 \mathrm{M}$ acetate buffer $(\mathrm{pH}$ $5.0)$ and $10 \mathrm{mg}(10,000$ units) of $\beta$-glucuronidase or $3 \mathrm{mg}$ (3.48 units) of aryl sulfatase preparation. After incubation for $6 \mathrm{hr}$ with glucuronidase or $20 \mathrm{hr}$ with sulfatase, the mixture was acidified to $\mathrm{pH} 1$ and extracted with ethyl acetate. The above two ethyl acetate extracts were used for the identification of metabolites by TLC and by the methods described above. Autoradiograms of the extract from urine are shown in Fig. 8. PAP and PAP oxon (3) were not found. Seven metabolites, PAP acid (4), PAP oxon acid (5), demethyl PAP (6), demethyl PAP acid (8), demethyl PAP oxon acid (9), $\mathrm{MeSCH}(\mathrm{Ph}) \mathrm{COOH}$ (29), and $\mathrm{MeS}\left(\mathrm{O}_{2}\right) \mathrm{CH}(\mathrm{Ph})-$ $\mathrm{COOH}$ (31), were identified. However, eight metabolites remain unidentified. Intentional search for PAP $S$-isomer (2) and PAP phosphinyl disulfide $(\mathbf{1 0})$ failed. Also, treatment with $\beta$-glucuronidase and aryl sulfatase preparations did not give any solubilization in ethyl acetate

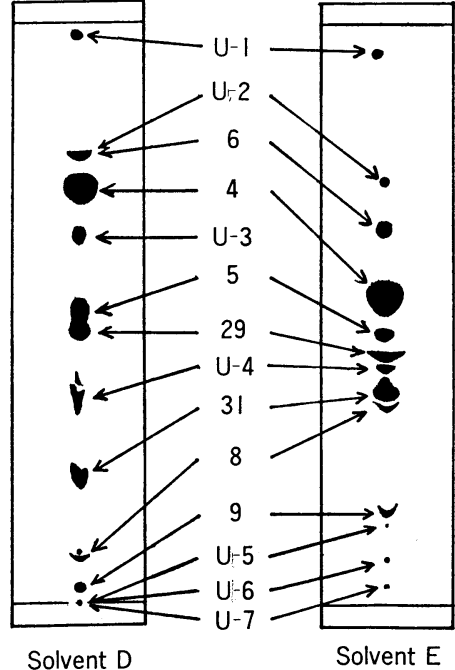

Fig. 8 TLC autoradiograms of metabolites of ${ }^{14} \mathrm{C}$-PAP in urine.

Table 7 Relative amounts of PAP metabolites excreted into urine during $24 \mathrm{hr}$ after oral administration of $43.8 \mathrm{mg} / \mathrm{kg}$ of ${ }^{14} \mathrm{C}-\mathrm{PAP}$.

\begin{tabular}{lc}
\hline \multicolumn{1}{c}{ Metabolite } & $\begin{array}{c}\% \text { of } \\
\text { administrated } \\
\text { radiocarbon }\end{array}$ \\
\hline MeSCH(Ph)COOH (29) & 8.78 \\
PAP acid (4) & 34.03 \\
Demethyl PAP (6) & 3.50 \\
PAP oxon acid (5) & 2.75 \\
Demethyl PAP acid (8) & 1.74 \\
Demethyl PAP oxon acid $(\mathbf{9})$ & 5.05 \\
MeS(O)CH(Ph)COOH (31) & 10.20 \\
U-1 & 1.34 \\
U-2 & 0.37 \\
U-3 & 1.60 \\
U-4 & 3.72 \\
U-5 & 0.09 \\
U-6 & 0.14 \\
U-7 & 0.15 \\
Aqueous fraction & 20.98 \\
\hline Total & 94.44 \\
\hline
\end{tabular}

of radiocarbon from aqueous fraction. Quantitation of these metabolites is shown in Table 7. Feces collected until 6 days represented 1.1\% of applied radioactivity, from which unchanged PAP $(0.52 \%)$ and ethyl mandelate (26) $(0.04 \%)$ as well as 6 unidentified metabolites were found (Fig. 9). PAP metabolites in mice have been 


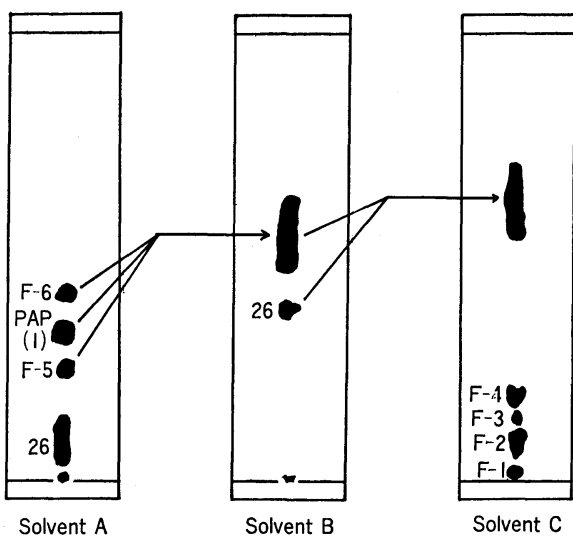

Fig. 9 TLC autoradiograms of metabolites of ${ }^{14} \mathrm{C}-\mathrm{PAP}$ in feces.

investigated by Takade $e$ al. ${ }^{2)}$ Using ${ }^{32} \mathrm{P}$ - and ${ }^{14} \mathrm{C}-\mathrm{PAP}$, they found demethyl PAP oxon (7), mandelic acid (27), $[-\mathrm{SCH}(\mathrm{Ph}) \mathrm{COOEt}]_{2}$ (23), $[-\mathrm{SCH}(\mathrm{Ph}) \mathrm{COOH}]_{2}(\mathbf{2 5})$ as well as $(\mathrm{MeO})_{2} \mathrm{P}(\mathrm{S})-$ $\mathrm{SH}$ and $(\mathrm{MeO})_{2} \mathrm{P}(\mathrm{S}) \mathrm{OH}$ other than those found by us. They also found trace amounts of PAP and PAP oxon in feces. On the other hand, we newly found PAP oxon acid (5) and $\mathrm{Me}-$ $\mathrm{S}(\mathrm{O}) \mathrm{CH}(\mathrm{Ph}) \mathrm{COOH}(\mathbf{3 1})$.
Based on the identification of the transformation products of PAP under various conditions including mice, metabolic reactivity of $\mathrm{PAP}$ is considered as shown in Fig. 10. Initial modifications seem to occur in five ways on the PAP molecule: i) hydrolysis of carboxy ethyl ester $(\mathbf{1} \rightarrow \mathbf{4})$; ii) demethylation $(\mathbf{1} \rightarrow \mathbf{6})$; iii) formation of phosphorus oxythionate $(\mathbf{1} \rightarrow \mathbf{X})$; iv) cleavage of $\mathrm{C}-\mathrm{S}$ bond $(\mathbf{1} \rightarrow \mathbf{2 6}) ; \mathrm{v})$ isomerization $(\mathbf{1} \rightarrow$ 2). Modification i) is catalyzed by carboxyesterase of microsome or cytosol origin. Modification ii) proceeds by GSH $S$-transferase-GSH system.

Modification iii) occurs by mixed function oxidase system. However, mechanism of formation of ethyl mandelate (26) is not certain. Seemingly, hydrolysis occurs simply. However, there was a positive effect of NADPH when microsome was used, and cytosol also catalyzed the reaction without GSH. When benzyl position is hydroxylated, the product seems to be unstable and hydrolyzed to PhCOCOOEt (33). But compound $\mathbf{3 3}$ and its corresponding acid (34) were not found under any conditions examined. Oxidation at thiolo sulfur followed by hydrolysis to ethyl mandelate (26) is only assumed at this point. Ethyl mandelate may

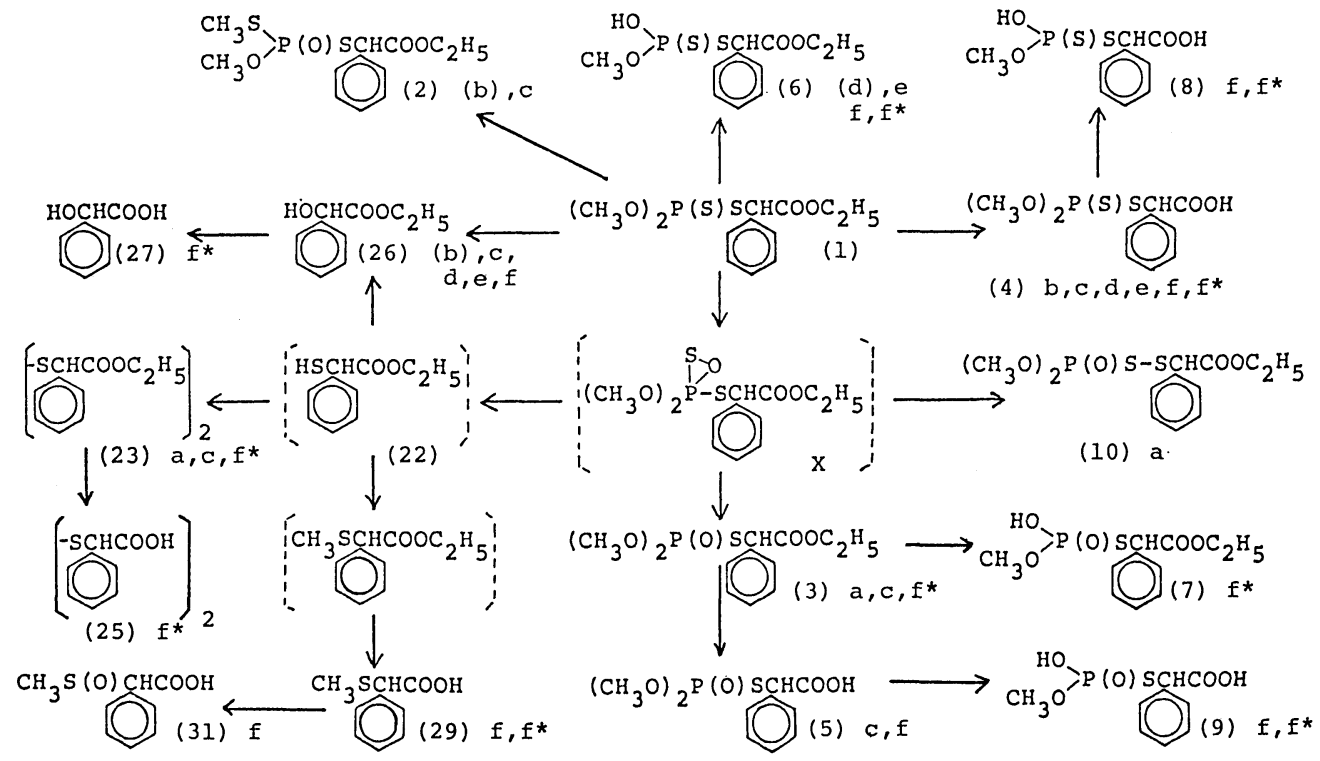

Fig. 10 Metabolic reactivity of PAP.

a: MCPBA, b: microsome, c: microsome-NAD-PH, d: cytosol, e: cytosol-

GSH, f: mice, $\mathrm{f}^{*}$ : mice by Takade et al., ( ): minor production. 
also be produced from intermediate $\mathbf{X}$ through compound 22. Such replacement of benzylic $\mathrm{SH}$ with $\mathrm{OH}$ group was observed for $\mathrm{ClC}_{6} \mathrm{H}_{4-}$ $\mathrm{CH}_{2} \mathrm{SH}$ in rat. ${ }^{8)}$ Isomerization of PAP to its thiolo isomer (2) did occur under in vitro microsomal conditions. Such thiono-thiolo isomerization had not been recognized under biological conditions, but our recent work $^{7}$ indicated that this isomerization was rather common. However, further modifications will not allow its finding under in vivo conditions. Many secondary reactions follow the initial modifications, resulting in various products illustrated in Fig. 10.

\section{ACKNOWLEDGMENTS}

We wish to express our thanks to members of the Radioisotope Research Institute, Tokyo University of Agriculture for their great help to our experiment. We also thank Dr. Kanju Ohsawa of NODAI Research Institute for providing assistance for the measurement GC-MS. This study was supported in part by grant-in-aid from Nissan Chemical Industries, Ltd. and Sumitomo Chemical Co., Ltd.

\section{REFERENCES}

1) M. Hirose, I. Miyata, T. Saito \& M. Hayashi: Botyu Kagaku 36, 43 (1971)

2) D. Y. Takade, T. Allsup, A. Khasawinah, T. S. Kao \& T. R. Fukuto: Pestic. Biochem. Physiol. 6, 367 (1976)

3) D. Y. Takade, M. S. Seo, T. S. Kao \& T. R. Fukuto: Arch. Environ. Contam. Toxicol. 5, 63 (1976)

4) N. Mikami, H. Ohkawa, \& J. Miyamoto: $J$.
Pesticide Sci. 2, 279 (1977)

5) H. Ohkawa, N. Mikami, K. Kasamatsu \& J. Miyamoto: J.Agric. Food Chem. 40, 1857 (1976)

6) T. Miyamoto \& I. Yamamoto: Agric. Biol. Chem. 44, 2581 (1980)

7) T. Miyamoto, K. Toeda \& I. Yamamoto: $J$. Pesticide Sci. 8, 613 (1983)

8) K. Ishikawa, I. Okuda \& S. Kuwatsuka: Agric. Biol. Chem. 37, 165 (1973)

\section{要約}

\section{哺乳動物系における phenthoate の新代謝物}

戸枝一喜, 宮本 徹, 加藤 茂, 山本 出 Phenthoate (PAP) $\left[\left(\mathrm{CH}_{3} \mathrm{O}\right)_{2} \mathrm{P}(\mathrm{S}) \mathrm{SCH}(\mathrm{Ph}) \mathrm{COOC}_{2} \mathrm{H}_{5}\right]$ からの 12 種の変化生成物をマウス, ラット肝画分, 過 酸により同定した。すずに報告されている化合物のほか に，5種の生成物が新規に見いだされた： $\left(\mathrm{CH}_{3} \mathrm{O}\right)_{2} \mathrm{P}(\mathrm{O})-$ $\mathrm{SCH}(\mathrm{Ph}) \mathrm{COOH}$ [マウス，ミクロゾーム- $\mathrm{NADPH}$ 系 (mfo)], $\mathrm{CH}_{3} \mathrm{~S}(\mathrm{O}) \mathrm{CH}(\mathrm{Ph}) \mathrm{COOH}$ [マウス], $\mathrm{HOCH}(\mathrm{Ph})-$ $\mathrm{COOC}_{2} \mathrm{H}_{5}$ [マウス, mfo, サイトソル], $\left(\mathrm{CH}_{3} \mathrm{~S}\right)\left(\mathrm{CH}_{3} \mathrm{O}\right)-$ $\mathrm{P}(\mathrm{O}) \mathrm{SCH}(\mathrm{Ph}) \mathrm{COOC}_{2} \mathrm{H}_{5}$ (PAP $S$-isomer) $[\mathrm{mfo}],\left(\mathrm{CH}_{3} \mathrm{O}\right)_{2-}$ $\mathrm{P}(\mathrm{O}) \mathrm{SSCH}(\mathrm{Ph}) \mathrm{COOC}_{2} \mathrm{H}_{5}$ (phosphinyl disulfide) [過酸 酸化]. 代謝物同定に基づきPAP の代謝経路を推定した ところ, PAP は次の 5 通りの変化をまず受け，さらに 2 次的に種々の生成物を与えると思われる：i）カルボキ シエチルエステルの加水分解，ii)脱メチル化，iii) phosphorus oxythionate の形成，iv) C-S 結合の開裂，v) 異性化. mfo による PAP S-isomer, 過酸酸化による phosphinyl disulfide はマウス中においても生成したも のと考えられるが，不安定なため見いだされないのであ ろう。 